\title{
An Experimental and Kinetic Modelling Study for Methane Oxidation over Pd-based Catalyst: Inhibition by Water
}

\author{
Nadezda Sadokhina ${ }^{1} \cdot$ Farideh Ghasempour $^{1} \cdot$ Xavier Auvray $^{1}$ Gudmund Smedler $^{2}$. \\ Ulf Nylén ${ }^{3} \cdot$ Marcus Olofsson ${ }^{4} \cdot$ Louise Olsson $^{1}$
}

Received: 11 October 2016 / Accepted: 30 June 2017 / Published online: 8 July 2017

(c) The Author(s) 2017. This article is an open access publication

\begin{abstract}
The water inhibition of methane oxidation over a bimetallic $\mathrm{Pt}-\mathrm{Pd}$ on $\mathrm{CeO}_{2}-\mathrm{Al}_{2} \mathrm{O}_{3}$ catalyst was investigated and the experimental data were used to develop a kinetic model, consisting of only three reaction steps. In the model, the water effect was assigned to the adsorption of $\mathrm{H}_{2} \mathrm{O}$ on surface sites, as well as to the formation and accumulation of surface hydroxyl groups. These two effects were accounted by the model, which could well describe the experimental data obtained under various conditions.
\end{abstract}

\section{Graphical Abstract}

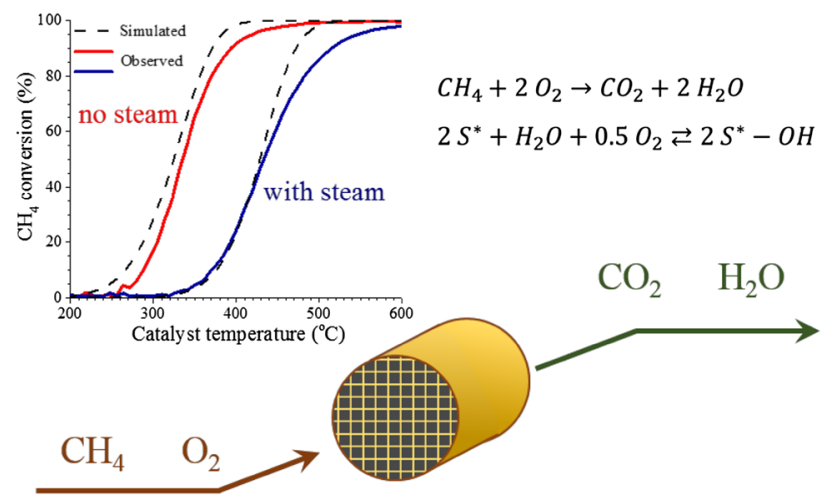

Louise Olsson

louise.olsson@chalmers.se

1 Chemical Engineering, Competence Centre for Catalysis, Chalmers University of Technology, 41296 Gothenburg, Sweden

2 Johnson Matthey AB, 42131 Västra Frölunda, Sweden

3 Scania CV AB, 15187 Södertälje, Sweden

4 AVL MTC Motortestcenter AB, P. O. Box 223, 13623 Haninge, Sweden
Keywords Methane oxidation $\cdot \mathrm{Pd} \cdot$ Water inhibition · Kinetic modelling

\section{List of Symbols}

\section{Nomenclature}

$A_{i} \quad$ Pre-exponential factor for reaction $i\left(\mathrm{kmol} /\left(\mathrm{m}^{2} \mathrm{~s}\right)\right.$

CPSI Cell density per square inch $\left(\mathrm{in}^{-2}\right)$

$D \quad$ Noble metal dispersion (-)

$d_{D} \quad$ Average particle size (nm)

$d_{\text {hyd }} \quad$ Hydraulic diameter of the channel (m)

$E_{A, i} \quad$ Activation energy for reaction $i(\mathrm{~J} / \mathrm{mol})$

$G S A \quad$ Geometric surface area per reactor volume $\left(\mathrm{m}^{-1}\right)$

$G z_{\text {mass }}$ The Graetz number for mass transfer

$k_{i} \quad$ Rate constant for reaction $i\left(\mathrm{~s}^{-1}\right)$

$k_{k, m} \quad$ Mass transfer coefficient of species $k\left(\mathrm{~mol} / \mathrm{m}^{2} \mathrm{~s}\right)$

$M G_{k, g} \quad$ Molar mass of gas phase species $k(\mathrm{~kg} / \mathrm{kmol})$

$r_{i} \quad$ Reaction rate for reaction $i\left(\mathrm{kmol} /\left(\mathrm{m}^{2} \mathrm{~s}\right)\right)$

Re The Reynolds number

Sc The Schmidt number

Sh The Sherwood number

$T_{s} \quad$ Temperature at catalyst surface $(\mathrm{K})$

$t \quad$ Time (s)

$v_{g} \quad$ Gas velocity $(\mathrm{m} / \mathrm{s})$

$v_{i, k} \quad$ Stoichiometric coefficient of species $k$ in reaction $i$ $(-)$

$w_{k, g} \quad$ Mass fraction of species $k$ in gas phase (-)

$y_{k} \quad$ Mole fraction at the reaction layer of species $k(-)$

$y_{k}^{B} \quad$ Mole fraction in the gas bulk of specie $k(-)$

$z \quad$ Spatial coordinate in axial direction (m)

\section{Greek Symbols}

$\alpha_{i} \quad$ Coverage dependence in reaction $i(-)$

$\delta_{\text {wall }} \quad$ Monolith wall thickness $(\mu \mathrm{m})$

$\delta_{w c} \quad$ Monolith washcoat thickness $(\mu \mathrm{m})$ 
$\epsilon_{g} \quad$ Volume fraction of gas phase in entire system (-)

$\theta_{k} \quad$ Coverage of species $k(-)$

$\rho_{g} \quad$ Density of gas phase $\left(\mathrm{kmol} / \mathrm{m}^{3}\right)$

$\Theta \quad$ Surface site density of storage site $\left(\mathrm{mol} / \mathrm{m}^{2}\right)$

\section{Introduction}

In general, noble metal-based materials are considered to be efficient catalysts for the oxidation of short chain hydrocarbons including methane. High activity in methane oxidation has resulted in the implementation of $\mathrm{Pd}$-containing materials into the aftertreatment systems utilized for the reduction of emissions from natural gas vehicles (NGVs) [1-3]. However, the catalytic activity of these systems is decreasing with time-on-stream and significant research has been addressed to understand the mechanism of Pdbased catalyst deactivation during the methane oxidation. The water inhibition effect has been discussed extensively [4-15] and the formation of surface hydroxyls is considered to be a key deactivation pathway, which results in the slow deactivation of the catalyst due to the continuous formation and accumulation of these surface species [8, 16]. Moreover, it was shown that competitive adsorption between methane and water molecules plays a role in the catalytic activity loss $[5,9,15,17,18]$. However, the precise mechanism of deactivation in the presence of water vapour is still unclear.

Kinetic models provide important information to understand reaction mechanisms, as well as the models are used for prediction and optimization of chemical processes. Trinchero et al. [19] developed a detailed kinetic model for methane oxidation over single Pd crystal based on ab initio simulations, resulting in 11 reversible reactions. Peskov et al. [20] also performed a theoretical study, in which a micro kinetic model for oscillations during methane oxidation was developed. A model for the oxidation/reduction cycle over polycrystalline $\mathrm{Pd} / \mathrm{PdO}_{\mathrm{x}}$ was derived by Wolf et al. [21]. There are also a few kinetic models available for methane oxidation in the presence of water vapour. For methane oxidation most commonly the Langmuir-Hinshelwood-Hougen-Watson (LHHW) type of the rate equations is used in literature [22-28]; however, Mars-van Krevelen (MVK) based equations can also be used to describe mechanism of methane oxidation [29, 30]. The oxidation of $\mathrm{CH}_{4}$ over $\mathrm{PdO}$ is strongly inhibited by $\mathrm{H}_{2} \mathrm{O}$, with a negative reaction order (-1) [15]. Groppi et al. [22, 23] used a pseudo LHHW kinetic model $\left(R_{w}=K_{r} C_{C_{4}} /\left(1+K_{H_{2} O} C_{H_{2} O}\right)\right)$ to describe methane oxidation over $\mathrm{PdO} / \mathrm{Al}_{2} \mathrm{O}_{3}$. The model could adequately describe the steady state conversion of methane when varying methane and water concentrations. Fernández et al. [24] and Abbasi et al. [25] have also successfully used this rate expression for their methane oxidation simulations over $\mathrm{Pd}-$ and $\mathrm{Pt}-\mathrm{Pd}$-based catalysts, respectively. Moreover, detailed modelling work on methane oxidation with a focus on water inhibition was performed by Hurtado et al. [29]. Various rate equations based on Langmuir-Hinshelwood (LH), Eley-Rideal (ER), and MVK mechanisms were investigated and it was concluded that experimental data obtained on $\mathrm{Pd}$ /alumina can be successfully modelled by the MVK mechanism. In this study, modelling of steady state data was also performed. Specchia et al. [30] examined different models for steady state methane oxidation under dry conditions over $\mathrm{Pd} /$ $\mathrm{Ce}_{x} \mathrm{Zr}_{1-x} \mathrm{O}_{2}$, including the above mentioned mechanism, and found that MVK is the best mechanism to describe the experimental data. Inhibiting effect of water on methane oxidation under transient conditions has been also studied by Kikuchi et al. [4] and recently by Alyani and Smith [31]. Kikuchi et al. [4] demonstrated experimentally that the $\mathrm{Pd} /$ $\mathrm{Al}_{2} \mathrm{O}_{3}$ catalyst has been deactivated by water, and derived rate parameters for the system. However, these parameters were not used to model any experimental data [4]. Based on a simplified kinetic model of methane oxidation in the presence of water Alyani and Smith [31] demonstrated the Ce-promoting effect on the $\mathrm{Pd} / \mathrm{Al}_{2} \mathrm{O}_{3}$ catalyst. The data showed that the equilibrium constant for water adsorption was lower and that the water desorption rate was higher on the Ce-containing sample resulting in lower loss in catalytic activity.

Thus, there are a few kinetic models that describe methane oxidation over palladium containing catalysts in the presence of water, but these models mostly focus on steady state reaction conditions. The recent modelling study by Alyani and Smith [31] accounts transient inhibition by water at different temperatures. However, there is still lack of data on methane oxidation under complex conditions. To our knowledge, there are no transient kinetic models that describe variation in concentrations of different gases such as water and NO during methane oxidation, which is the objective of this study. In greater details, a well-characterized Pt-Pd-based catalyst was used to experimentally investigate the activity and selectivity in methane oxidation varying concentrations of gas phase components: $\mathrm{CH}_{4}, \mathrm{NO}$, $\mathrm{CO}, \mathrm{O}_{2}$ and $\mathrm{H}_{2} \mathrm{O}$. Based on these data, a kinetic model was developed that is capable to simulate features of the transient experiments over time.

\section{Experimental Part}

\subsection{Sample Preparation and Activity Measurements}

Powder of a catalyst synthesized by an impregnation method was washcoated on a ceramic monolith (diameter $=21 \mathrm{~mm}$, length $=20 \mathrm{~mm} ; 400 \mathrm{cpsi}$, mass of 
washcoat $=500 \mathrm{mg}$ ). The catalyst contained $0.6 \mathrm{wt} \%$ $\mathrm{Pt}, 3.2 \mathrm{wt} \% \mathrm{Pd}$ and $20 \mathrm{wt} \% \mathrm{CeO}_{2}$ on $\delta-\mathrm{Al}_{2} \mathrm{O}_{3}$. Details on the catalyst synthesis can be found in [32]. The monolith sample was placed into a quartz flow reactor using insulation around the monolith to avoid gases bypassing. First, the sample was pre-treated at $500^{\circ} \mathrm{C}$ in $2 \% \mathrm{H}_{2}$ in Ar flow for $30 \mathrm{~min}$. The temperature was then increased up to $70{ }^{\circ} \mathrm{C}$ in $\mathrm{Ar}$ flow to perform a degreening of the sample in order to ensure stability during the different experiments. At this temperature, the monolith was treated twice for 60 min under lean conditions $\left(500 \mathrm{ppm} \mathrm{CH}_{4}, 500 \mathrm{ppm}\right.$ $\mathrm{NO}, 300 \mathrm{ppm} \mathrm{CO}, 8 \% \mathrm{O}_{2}, 5 \% \mathrm{H}_{2} \mathrm{O}$, balanced by $\mathrm{Ar}$ ) with a treatment under rich conditions $\left(2 \% \mathrm{H}_{2}, 5 \% \mathrm{H}_{2} \mathrm{O}, \mathrm{Ar}\right)$ for $20 \mathrm{~min}$ in-between lean steps. Thereafter, the sample was purged by Ar for $10 \mathrm{~min}$ and was pre-treated using $8 \% \mathrm{O}_{2}$, $5 \% \mathrm{H}_{2} \mathrm{O}$ in Ar flow for $30 \mathrm{~min}$ at $700^{\circ} \mathrm{C}$. The sample was then cooled down to $150^{\circ} \mathrm{C}$ in Ar flow and catalytic activity tests were performed.

The activity of the sample was measured ramping up and down the temperature in the range of $150-700^{\circ} \mathrm{C}$ at a ramp rate of $5 \%$ min under lean conditions. The following gas compositions were used: Ramp 1: $500 \mathrm{ppm} \mathrm{CH}_{4}$ and $8 \% \mathrm{O}_{2}$, Ramp 2: 500 ppm $\mathrm{CH}_{4}, 8 \% \mathrm{O}_{2}$ and $5 \% \mathrm{H}_{2} \mathrm{O}$ and Ramp 3: 500 ppm $\mathrm{CH}_{4}, 500$ ppm NO, 300 ppm CO, $8 \% \mathrm{O}_{2}$ and $5 \% \mathrm{H}_{2} \mathrm{O}$. The total gas flow was held constant at $3500 \mathrm{ml} / \mathrm{min}\left(\mathrm{GHSV} 30,000 \mathrm{~h}^{-1}\right.$ ) and was balanced by Ar. The outlet gas composition was monitored by an MKS MultiGas 2030 HS FTIR gas spectrometer. The sample was pre-treated at $700{ }^{\circ} \mathrm{C}$ for 30 min using $8 \% \mathrm{O}_{2}, 5 \% \mathrm{H}_{2} \mathrm{O}$ in $\mathrm{Ar}$ flow and thereafter cooled in Ar only prior to Ramp 1 and Ramp 2, which resulted in a clean Pt-Pd surface. However, Ramp 3 was conducted directly after Ramp 2, without any pre-treatment, resulting in adsorbates left on the surface from the previous Ramp 2.

The same set-up was used to perform experiments at constant temperature where concentrations of $\mathrm{CH}_{4}, \mathrm{NO}$, $\mathrm{CO}, \mathrm{O}_{2}$ and $\mathrm{H}_{2} \mathrm{O}$ varied step-by-step as shown in Fig. 1. Prior to each isothermal activity test, the catalyst was pretreated using $8 \% \mathrm{O}_{2}$ and $5 \% \mathrm{H}_{2} \mathrm{O}$ in Ar flow for $30 \mathrm{~min}$ at $700{ }^{\circ} \mathrm{C}$ and cooled down to 350 or $450^{\circ} \mathrm{C}$, respectively, in Ar only flow.

\subsection{Catalyst Characterization}

The dispersion of noble metals was measured by $\mathrm{CO}$ chemisorption using a pulse flow technique at room temperature [33] in the same set-up as described in Sect. 2.1. Prior to the measurement, the sample was subjected to a thermal pre-treatment which involved a reduction at $500^{\circ} \mathrm{C}$ under $2 \% \mathrm{H}_{2}$ in Ar flow for $30 \mathrm{~min}$ followed by fast cooling to $25^{\circ} \mathrm{C}$ in the same gas flow. After flushing with Ar flow for $10 \mathrm{~min}$, the sample was exposed to a mixture of $100 \mathrm{ppm}$ $\mathrm{CO}$ and $0.5 \% \mathrm{CO}_{2}$ (to avoid $\mathrm{CO}$ adsorption on ceria [34]) in

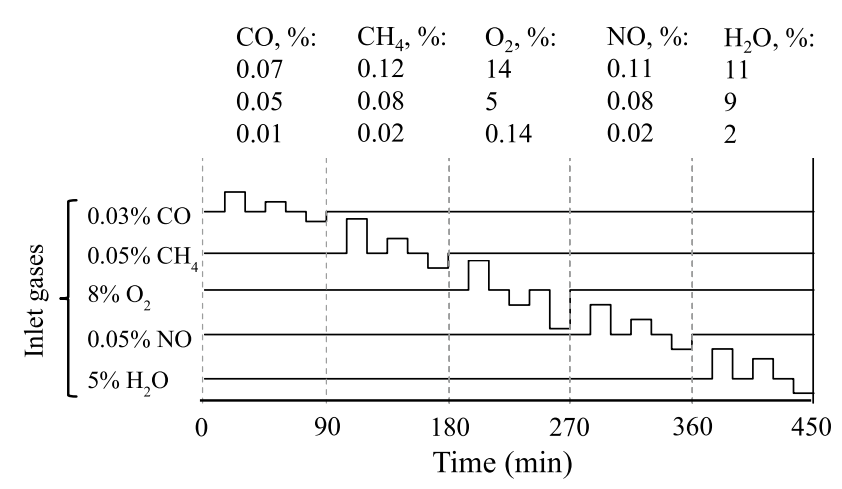

Fig. 1 Changing the inlet gas composition stepwise during the methane oxidation over $\mathrm{Pt}-\mathrm{Pd} / \mathrm{CeO}_{2}-\mathrm{Al}_{2} \mathrm{O}_{3}$ catalyst at constant temperature

Ar for 20 min to measure the $\mathrm{CO}$ adsorption. Physisorbed $\mathrm{CO}$ was then flushed away with $0.5 \% \mathrm{CO}_{2}$ in $\mathrm{Ar}$ for $10 \mathrm{~min}$ and a second pulse of $100 \mathrm{ppm} \mathrm{CO}$ and $0.5 \% \mathrm{CO}_{2}$ was performed to quantify the weakly bonded $\mathrm{CO}$. The overall noble metal dispersion was determined using temperature programmed desorption of $\mathrm{CO}$ in Ar flow (CO-TPD) performed at a ramp rate of $10^{\circ} / \mathrm{min}$ up to $500^{\circ} \mathrm{C}$. During CO adsorption and CO-TPD measurements, a total gas flow of $1000 \mathrm{ml} / \mathrm{min}$ was used. For the estimation of the noble metal dispersion, adsorption stoichiometry of 1:1 for both CO:Pd and CO:Pt was assumed [35-38].

A transmission electron microscopy (TEM) analysis was performed to examine the particle size of the bimetallic catalyst $\mathrm{Pt}-\mathrm{Pd} / \mathrm{CeAl}_{2} \mathrm{O}_{3}$, as well as to study if any alloys between $\mathrm{Pt}$ and $\mathrm{Pd}$ had been formed. After the catalytic activity tests, a portion of catalyst powder was scraped off from the washcoat layer of the monolith for TEM analysis. The sample was pestled in an agate mortar and then placed on a carbon film using TEM $\mathrm{Cu}$ grids. The particles were imaged using an FEI Titan 80-300 TEM with a probe Cs (spherical aberration) corrector operated at $300 \mathrm{kV}$. The images were recorded using a high angle annular dark field (HAADF) detector in the scanning TEM imaging mode (STEM), providing a $\mathrm{Z}$ number contrast. The electron probe size for this study was about $0.2 \mathrm{~nm}$. The chemical characterization of particles was performed by energy dispersive X-ray (EDX) spectroscopy.

\section{Kinetic Modelling}

\subsection{Reactor Model}

The kinetic model for methane oxidation activity of $\mathrm{Pt}-\mathrm{Pd} / \mathrm{CeO}_{2}-\mathrm{Al}_{2} \mathrm{O}_{3}$ was developed using a commercial software, AVL BOOST. The catalyst parameters applied into the model development are shown in Table 1 and the 
Table 1 The parameters for the monolith sample (square cell type specification) used in the simulations

\begin{tabular}{ll}
\hline Parameter name and unit & Value \\
\hline Cell density, $C P S I\left(\mathrm{in}^{-2}\right)$ & 400 \\
Wall thickness, $\delta_{\text {wall }}(\mu \mathrm{m})$ & 101.6 \\
Monolith diameter $(\mathrm{mm})$ & 21 \\
Monolith length $(\mathrm{mm})$ & 20 \\
Washcoat porosity $(\%)$ & 0.5 \\
\hline
\end{tabular}

temperature measured in the middle of the monolith was used in the simulations. One dimension (1D) single channel model was applied and the channel was discretized in the axial direction using 20 grid points with a grid shape factor equal to unity.

Mass transfer through the boundary layer was accounted for by the Hawthorn correlation, according to [39]:

Sh $=3.66+\left(1+0.095 \times G z_{\text {mass }}\right)^{0.45}$

which is based on the definition of the dimensionless Graetz numbers for mass $\left(G z_{\text {mass }}\right)$ transfer:

$G z_{\text {mass }}=\operatorname{Re} \times S c \times \frac{d}{l}$

where $S h$ is the Sherwood number, $R e$ is the Reynolds number, and $S c$ is the Schmidt number. For channel shaped monoliths, $d$ represents the hydraulic channel diameter and $l$ is the channel length.

Metkar et al. [40], found an average washcoat thickness of about $35 \mu \mathrm{m}$ for a loading of $0.15 \mathrm{~g} / \mathrm{cm}^{3}$ and in addition that doubling the washcoat gave ca double washcoat thickness [41]. Based on these data it was estimated that a monolith of $20 \mathrm{~mm}$ in length and $21-22 \mathrm{~mm}$ in diameter with a washcoat mass of $500 \mathrm{mg}$, which is the case of our sample, would yield a washcoat thickness of $15-17 \mu \mathrm{m}$. In the current model, the mass transfer in the washcoat was therefore simulated using five grid points and $17 \mu \mathrm{m}$ for the washcoat thickness $\left(\delta_{w c}\right)$. The mass balance equation was:

$\epsilon_{g} \frac{\partial \rho_{g} \times w_{k, g}}{\partial t}=\epsilon_{g} \frac{\partial \rho_{g} \times w_{k, g} \times v_{g}}{\partial z}+M G_{k, g} \sum_{i}^{n r} v_{i, k} \times r_{i}\left(y_{k}, T_{s}, \theta_{k}\right)$,

where the coverage of component $k$ on the surface was given by:

$\frac{\partial \theta_{k}}{\partial t}(\Theta \times G S A)=\sum_{i}^{n r} v_{i, k} \times r_{i}\left(y_{k}, T_{s}, \theta_{k}\right)$,

with the geometric surface area per unit reactor volume (channel wetted perimeter), GSA, derived from:

$\frac{G S A}{d_{\text {hyd }}}=4 \times(C P S I)$,
The external mass transport from the gas bulk to the surface was described by the film model, using the following equation:

$$
G S A \times k_{k, m} \times\left(y_{k}-y_{k}^{B}\right)=\sum_{i}^{n r} v_{i, k} \times r_{i}\left(y_{k}, T_{s}, \theta_{k}\right)
$$

The effective diffusion coefficient was evaluated according to a modified Wakao-Smith random pore model for monolith catalysts used in selective catalytic reduction (SCR) of $\mathrm{NO}_{\mathrm{x}}$ as reported by the Tronconi group [42, 43], where they determined the value to $5 \times 10^{-6} \mathrm{~m}^{2} / \mathrm{s}[42$, 44]. This value was successfully used in several models reported in literature [45-47]. The washcoat in our sample was intentionally thin, in order to minimize mass transfer in the washcoat and indeed simulations with and without mass transfer in the washcoat demonstrated the same results. However, mass transfer in the washcoat was anyway included in all simulations for completeness.

\subsection{Kinetic Model}

To simulate and capture the temperature dependence in the kinetic model, the Arrhenius Eq. (7) was used for rate constants $k_{i}$, according to:

$k_{i}=A_{i} \times e^{\frac{-E_{A, i}}{R \times T_{s}}}$,

where $A_{i}$ is the pre-exponential factor, $E_{A, i}$ is the activation energy, $R$ is the gas constant $(8.314 \mathrm{~J} /(\mathrm{mol} \mathrm{K}))$, and $T_{s}$ is the absolute temperature of the catalyst surface $(\mathrm{K})$.

The developed kinetic model consists of three reactions, which are shown below with their corresponding rate equations and parameters placed in Tables 2 and 3. The first reaction (R1) is a global step for $\mathrm{CH}_{4}$ oxidation.

$\mathrm{CH}_{4}+2 \mathrm{O}_{2} \rightarrow \mathrm{CO}_{2}+2 \mathrm{H}_{2} \mathrm{O}$

The conventional LHHW type of rate equation was tuned to the experimental data. It was assumed that adsorbed $\mathrm{CH}_{4}$ species are rapidly consumed resulting in zero coverage of active sites by methane molecules. Additionally, it was taken into account that methane oxidation is zero order in respect to $\mathrm{CO}_{2}$ and $\mathrm{O}_{2}$. This resulted in methane reaction rate expression where competitive adsorption of $\mathrm{H}_{2} \mathrm{O}$ and NO on active sites are taken into account:

$\mathrm{r}=\frac{\mathrm{k}_{1} \times \mathrm{y}_{\mathrm{CH}_{4}}}{1+\mathrm{k}_{\mathrm{H}_{2} \mathrm{O}}^{\text {inhib }} \times \mathrm{y}_{\mathrm{H}_{2} \mathrm{O}}+\mathrm{k}_{\mathrm{NO}}^{\text {inhib }} \times \mathrm{y}_{\mathrm{NO}}}$

The reaction rate is first order with respect to methane concentration, which is consistent with several models in the literature $[22-24,29,30]$. The model also contains a water inhibition term in the same way as the pseudo LHHW model that 
Table 2 Equations and kinetics parameters for methane oxidation based on activity experiments accompanied with data of the sensitivity analysis

\begin{tabular}{|c|c|c|c|c|c|}
\hline \# & Equation/reaction rate & $\begin{array}{l}\text { Pre-exponential factor } \\
\left(\mathrm{kmol} /\left(\mathrm{m}^{2} \mathrm{~s}\right)\right)\end{array}$ & $\begin{array}{l}\text { Activation } \\
\text { energy }(\mathrm{kJ} / \mathrm{mol})\end{array}$ & $\begin{array}{l}\text { Change in } \mathrm{S}(\%) \\
\text { Figs. } 6 \text { and } 7\end{array}$ & Change in S (\%) Fig. 8 \\
\hline R1 & $r_{R 1}=\frac{k_{1} \times y_{\mathrm{CH}_{4}} \times \theta_{S^{*}}}{1+k_{\mathrm{H}_{2} \mathrm{O}}^{\text {ihhib }} \times y_{\mathrm{H}_{2} \mathrm{O}}+k_{\mathrm{NO}}^{\text {inhib }} \times y_{\mathrm{NO}}}$ & $1.33 \times 10^{5}$ & $102^{\mathrm{a}}$ & $\begin{array}{l}\text { Pre-exp: } 0.37 \\
\text { Act.En: - }\end{array}$ & $\begin{array}{l}\text { Pre-exp: } 1.14 \\
\text { Act.En: - }\end{array}$ \\
\hline R2 & $r_{R 2}=k_{2} \times \theta_{S^{*}} \times y_{\mathrm{H}_{2} \mathrm{O}} \times y_{\mathrm{O}_{2}}-k_{-2} \times \theta_{S^{*}-\mathrm{OH}}$ & $\begin{array}{l}\text { Forward: } 3.82 \\
\text { Backward: } 7.38 \times 10^{-2}\end{array}$ & 130 & $\begin{array}{l}\text { Pre-exp: } 0.41 \\
\text { Act.En: } 5.64\end{array}$ & $\begin{array}{l}\text { Pre-exp: } 0.67 \\
\text { Act.En: } 43.44\end{array}$ \\
\hline & & & 158 & $\begin{array}{l}\text { Pre-exp: } 0.33 \\
\text { Act.En: } 8.95\end{array}$ & $\begin{array}{l}\text { Pre-exp: } 0.02 \\
\text { Act.En: } 0.47\end{array}$ \\
\hline R3 & $r_{R 3}=k_{3} \times y_{\mathrm{NO}} \times y_{\mathrm{O}_{2}}^{0.5}-\frac{k_{3}}{K_{e q}} \times y_{\mathrm{NO}_{2}}$ & Forward: 0.1 & 30 & Pre-exp: 0.06 & Pre-exp: 0.27 \\
\hline
\end{tabular}

${ }^{a}$ Calculated from experimental data. $k_{\mathrm{H}_{2} \mathrm{O}}^{\text {inhib }}$ has the form of $A_{\mathrm{H}_{2} \mathrm{O}}^{\text {inhib }} \times e^{\frac{\Delta H_{\mathrm{H}_{2} \mathrm{O}}^{\text {inhib }}}{R \times T_{s}}}$, where $A_{\mathrm{H}_{2} \mathrm{O}}^{\text {inhib }}$ and $\Delta H_{\mathrm{H}_{2} \mathrm{O}}^{\text {inhib }}$ were tuned to the experimental data, resulting in 0.68 and $40 \mathrm{~kJ} / \mathrm{mol}$. $k_{\mathrm{NO}}^{\text {inhib }}$ is a constant tuned to the experimental data, resulting in 10,500

Table 3 Additional parameters accompanied with data of the sensitivity analysis

\begin{tabular}{llll}
\hline Tuned parameter & Value & $\begin{array}{l}\text { Change in S (\%) } \\
\text { Figs. 6 and 7 }\end{array}$ & $\begin{array}{l}\text { Change } \\
\text { in S (\%) } \\
\text { Fig. 8 }\end{array}$ \\
\hline$A_{\mathrm{H}_{2} \mathrm{O}}^{\text {inhib }}$ & 0.68 & 0.29 & 0.41 \\
$\Delta H_{\mathrm{H}_{2} \mathrm{O}}^{\text {inhib }}$ & $40 \mathrm{~kJ} / \mathrm{mol}$ & 1.95 & 3.08 \\
$k_{\mathrm{NO}}^{\text {inhib }}$ & 10,500 & 0.06 & 0.24
\end{tabular}

Groppi et al. [22, 23] have described. However, this model could not account for the slow deactivation observed during transient experiments. In addition, this model could not describe the difference in light-off curves during cooling and heating, which will be discussed in the Sect. 4. In our earlier study it was proposed that there are two deactivation modes from water; the first one is fast deactivation relating to water adsorption and the second one is slow deactivation caused by hydroxyl species formation [32]. Our experimental data suggest that methane oxidation depends on active sites $\mathrm{S}^{*}$, which will be blocked by these species $\left(\mathrm{S}^{*}-\mathrm{OH}\right)$, resulting in that methane oxidation is hindered. These sites were added to model, resulting in that methane oxidation rate depends on active sites $S^{*}\left(\theta\left(S^{*}\right)=1-\theta\left(S^{*}-\mathrm{OH}\right)\right)$ which are affected by slow formation and accumulation of $-\mathrm{OH}$ groups according to the reaction R2. As can be seen in Fig. 2, the addition of active sites $\mathrm{S}^{*}$ improves the slope of the modelling data that approaches the slope of the experimental results (see Sect. 4). The rate expression used in the model presented in this paper is therefore.

$r_{R 1}=\frac{k_{1} \times y_{\mathrm{CH}_{4}} \times \theta_{S^{*}}}{1+k_{\mathrm{H}_{2} \mathrm{O}}^{\text {inhib }} \times y_{\mathrm{H}_{2} \mathrm{O}}+k_{\mathrm{NO}}^{\text {inhib }} \times y_{\mathrm{NO}}}$

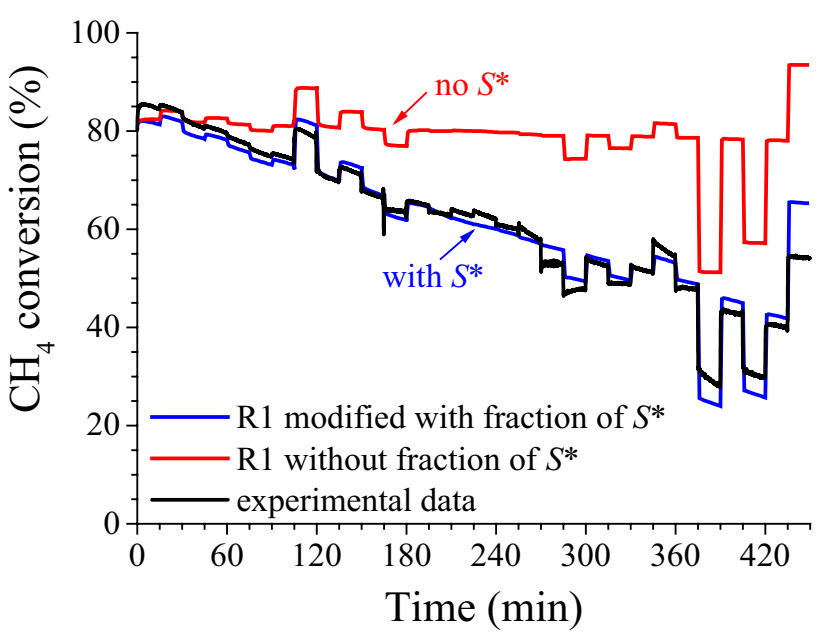

Fig. 2 Comparison of the modelling results taking into account active sites $S^{*}$ (blue curve) and excluding $S^{*}$ (red curve) from the reaction rate equation of the reaction $\mathrm{R} 1$

The LH water term in the denominator will account for the fast water deactivation and the addition of $\theta_{S^{*}}$ will account for the slow water deactivation, and thereby both deactivation modes observed experimentally [32] are present in the model.

The formation and decomposition of surface hydroxyl groups are added to the model by Reaction R2.

$2 S^{*}+\mathrm{H}_{2} \mathrm{O}+0.5 \mathrm{O}_{2} \rightleftarrows 2 S^{*}-\mathrm{OH}$

The reaction has the same form as was used in a detailed kinetic model for ammonia SCR over Cu/ZSM-5 [48] and the same formalism was found to be useful in this study, despite the significant differences between the systems under study. The importance of surface hydroxyl species is proposed based on the first-principle calculations [49]. 
Finally, reaction $\mathrm{R} 3$ describes a step for the reversible NO oxidation to $\mathrm{NO}_{2}$.

$\mathrm{NO}+0.5 \mathrm{O}_{2} \rightleftarrows \mathrm{NO}_{2}$

NO oxidation is an equilibrium reaction and the equilibrium constant $K_{e q}$ is calculated from the change in Gibbs free energy $(\Delta G)$ according to:

$K_{e q}=e^{\frac{-\Delta G}{R \times T_{s}}}$,

where

$\Delta G=\Delta H-T \times \Delta S$

The values of the enthalpy and entropy changes were calculated based on the values of standard enthalpy and standard entropy according to

$\mathrm{H}^{\circ}-\mathrm{H}_{298.15}^{\circ}=\mathrm{At}+\mathrm{Bt}^{2} / 2+\mathrm{Ct}^{3} / 3+\mathrm{Dt}^{4} / 4-\mathrm{E} / \mathrm{t}+\mathrm{F}-\mathrm{H}$,

$\mathrm{S}^{\circ}=\mathrm{A} \ln (\mathrm{t})+\mathrm{Bt}+\mathrm{Ct}^{2} / 2+\mathrm{Dt}^{3} / 3-\mathrm{E} /\left(2 \mathrm{t}^{2}\right)+\mathrm{G}$,

where coefficients were taken from the open thermodynamic database [50].

The kinetic parameters, except the activation energy for methane oxidation, were obtained by manual tuning in AVL BOOST software. The activation energy was retrieved by Arrhenius plot. In total, ten parameters were tuned in the model. In addition, optimization of the manually tuned parameters was performed in AVL design of experiments and optimization tool by Nelder-Mead method where a square difference between model and experimental data was used as a response parameter. However, the optimization did not result in further improvements of the model.

A sensitivity analysis of the kinetic parameters was performed using the transient experiments in Figs. 6, 7 and 8 in order to evaluate the relative sensitivity $(S)$ of each parameter on the simulation data. This analysis was performed using the same method presented in the study by Shwan et al. [51]. All the parameters have been increased and decreased by $1 \%$ where the residuals between the measured and simulated values of $\mathrm{CH}_{4}$ and $\mathrm{NO}$ were calculated and summarized. The sensitivity $(S)$ for each parameter was calculated using sum of square errors (SSE) according to

$S S E=\sum\left[\left(\mathrm{NO}^{\text {meas }}-\mathrm{NO}^{\text {sim }}\right)^{2}+\left(\mathrm{CH}_{4}^{\text {meas }}-\mathrm{CH}_{4}^{\text {sim }}\right)^{2}\right]$

where the upper and lower limits are shown in Tables 2 and 3 according to

$S=\left|\frac{S S E^{\text {original }}-S S E^{\text {changed }}}{S S E^{\text {original }}}\right| \times 100$

\section{Results and Discussion}

\subsection{Kinetic Model for Methane Oxidation Under Dry and Wet Conditions}

The $\mathrm{CO}$ chemisorption data resulted in an average dispersion of $6.7 \%$. The dispersion is a measure of the exposed particle surface, rather than an exact measurement of the number of active sites for the $\mathrm{CH}_{4}$ oxidation reaction. However, since the exact number of the active site is difficult to predict, the number of surface sites based on the dispersion value $(6.7 \%)$ was used in the model development. Moreover, the average particle size was calculated from TEM results (Fig. 3) assuming that the spherical metal particles were equally distributed over the support. Based on the particle size, noble metal dispersion was derived using a relation (16) given in the study by Gremminger et al. [35]:

$D=\frac{1.11}{d_{D}}$,

where $D$ is the noble metal dispersion $(0<D<1)$ and $d_{D}$ is the average particle size (expressed in $\mathrm{nm}$ ). This resulted in a dispersion of $6.2 \%$, which is in an excellent agreement with the data from $\mathrm{CO}$ chemisorption $(6.7 \%)$ used in the model. Furthermore, the EDX analysis showed both $\mathrm{Pt}$ and Pd in the examined particles, which indicates alloy formation.

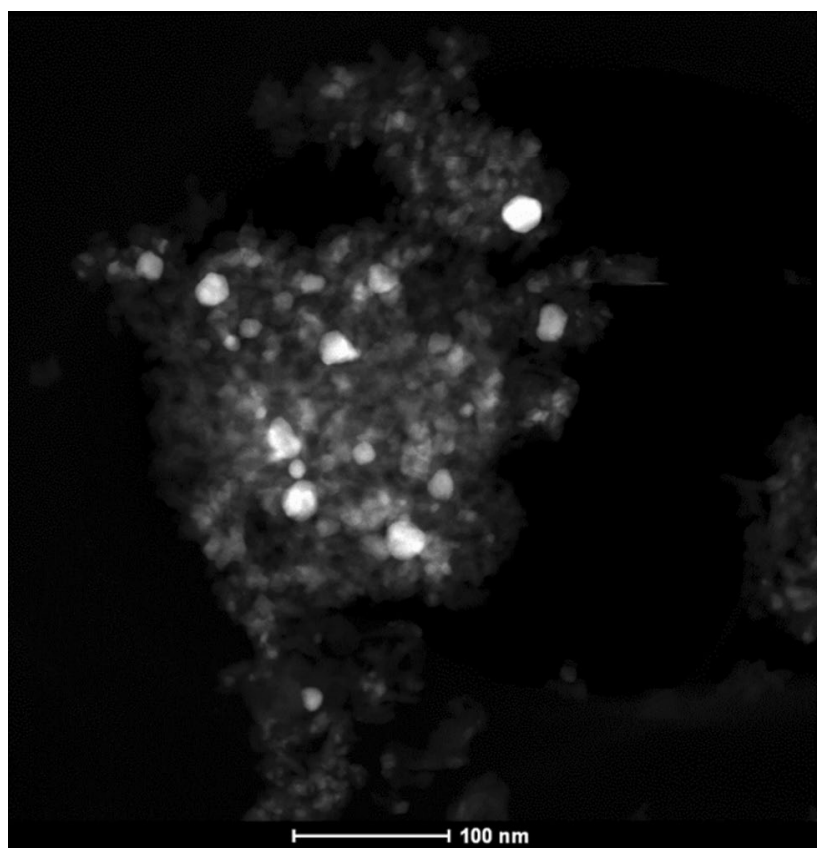

Fig. 3 Scanning TEM image of the model catalyst $\mathrm{Pt}-\mathrm{Pd} / \mathrm{CeO}_{2}-$ $\mathrm{Al}_{2} \mathrm{O}_{3}$ taken after catalytic activity measurements 


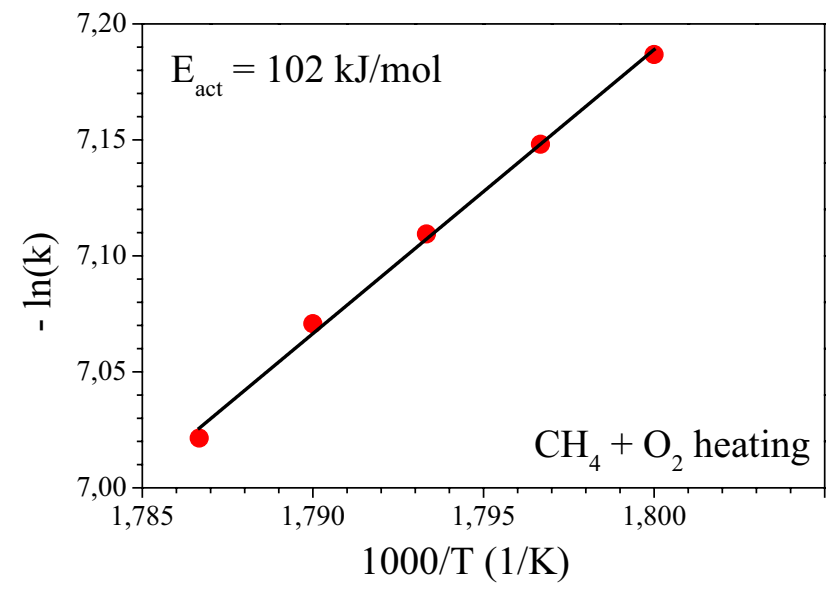

Fig. 4 Calculation of apparent activation energy from the Arrhenius plot

The apparent activation energy for methane oxidation (R1, Table 2) was estimated from the slope of the Arrhenius plot (Fig. 4) based on experimental results, when the $\mathrm{Pt}-\mathrm{Pd} / \mathrm{CeO}_{2}-\mathrm{Al}_{2} \mathrm{O}_{3}$ sample was exposed to merely $\mathrm{CH}_{4}$ and $\mathrm{O}_{2}$ containing mixture. The data were collected under $10 \%$ of methane conversion during the heating ramp of the experiment and resulted in an activation energy of $102 \mathrm{~kJ} /$ mol, which was used for all the simulations performed. The activation energies presented in the literature for methane oxidation over Pd-based catalysts span across a broad range from 60 to $190 \mathrm{~kJ} / \mathrm{mol}$ depending on the water presence and the type of support [15, 16, 29, 30, 52-54]. The three reactions and their corresponding rates shown in Tables 2 and 3 were used to simulate the methane oxidation experiments. The resulting parameters (Tables 2,3) were obtained by tuning the model to the experiments performed both under temperature programmed conditions and at constant temperature, in addition to the data from the Arrhenius plot (Fig. 4), and were used for all simulations shown in this study.

The catalyst was first exposed to a $\mathrm{CH}_{4}-\mathrm{O}_{2}$ gas mixture, and the resulting conversion is depicted in Fig. 5. A somewhat higher catalytic activity was found during the cooling than during the heating step, where e.g. the temperatures of $50 \%$ methane conversion $\left(\mathrm{T}_{50}\right)$ were $335^{\circ} \mathrm{C}$ and $319^{\circ} \mathrm{C}$ for heating and cooling, respectively. In Fig. 5 are also shown the results from the kinetic model. The model generally describes the activity for methane oxidation under dry conditions, without describing the temperature difference of $16^{\circ} \mathrm{C}$ for the cooling case. In the model, the cooling has slightly higher $\mathrm{T}_{50}$ compared to the heating due to minor water inhibition from water produced during methane oxidation according to the reaction $\mathrm{R} 1$. The reason for the hysteresis observed experimentally under the dry case was the formation and decomposition of palladium oxides.

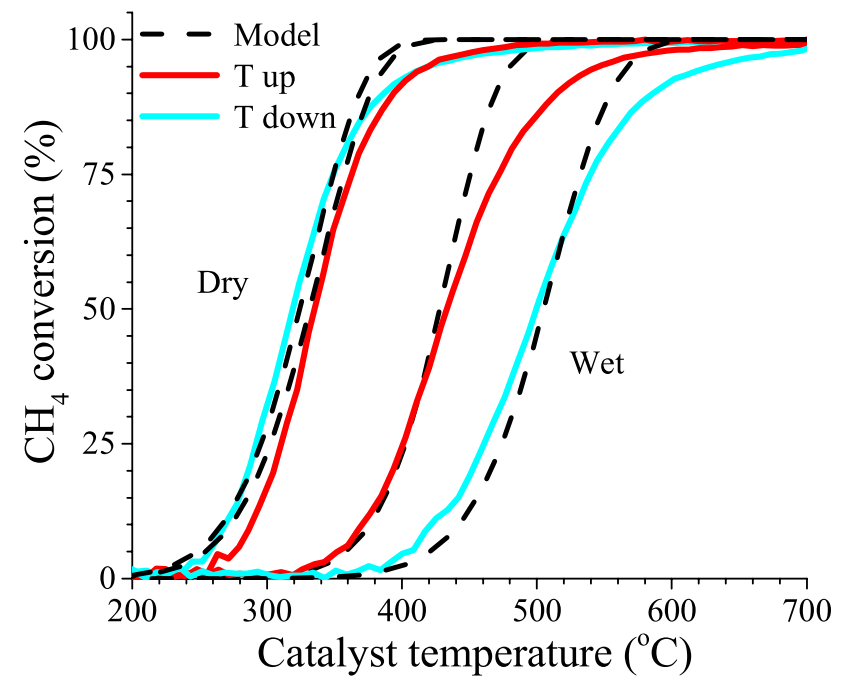

Fig. 5 Data of methane oxidation (solid line) accompanied by data of kinetic model (dashed line) under heating (red) and cooling (cyan) in a temperature range of $150-700^{\circ} \mathrm{C}$ using the following gas mixture: $500 \mathrm{ppm} \mathrm{CH}_{4}, 8 \% \mathrm{O}_{2}$, Ar without and with $5 \% \mathrm{H}_{2} \mathrm{O}$ addition marked as 'dry' and 'wet', respectively

However, the current model focuses on the substantial water inhibition effect and in order not to further complicate the model, steps for reoxidation of Pd were not introduced at this stage. The presence of water in the gas flow drastically lowered the activity resulting in $\mathrm{T}_{50}$ of 433 and $500^{\circ} \mathrm{C}$ for heating and cooling, respectively. Compared with $\mathrm{T}_{50}$ obtained under dry conditions, the increase was as dramatical as 98 and $181^{\circ} \mathrm{C}$ for the heating and cooling cases. The reaction rate for the methane oxidation (R1, Table 2) contained an inhibition term for water, in a similar way as was shown in the study by Groppi et al. [22, 23] and Fernández et al. [24]. This term provided an immediate effect of water and only depended on water concentration without changing over time. Analyzing the data in Fig. 5, one can observe that the ramp curve during heating under water presence was shifted by $98^{\circ} \mathrm{C}$ and this shift was possible to explain with a kinetic model consisted only the water inhibition in the denominator. However, during cooling the water effect became even more dramatical, resulting in a $\mathrm{T}_{50}$ increase of $181^{\circ} \mathrm{C}$ compared with the dry conditions. The kinetic model could not simulate such a large $\mathrm{T}_{50}$ increase simultaneously with $98^{\circ} \mathrm{C} \mathrm{T}_{50}$ growth for the heating step using only one water inhibition term. In a similar experiment (data not shown here), when the temperature ramp was repeated in the presence of water, the heating step of the second ramp demonstrated slightly higher $\mathrm{T}_{50}$ than the cooling in the first ramp and thereafter similar value for the second cooling [32]. Thus, two water effects were observed: first, an immediate catalytic activity loss and, secondly, a slow deactivation originating from the hydroxyl 


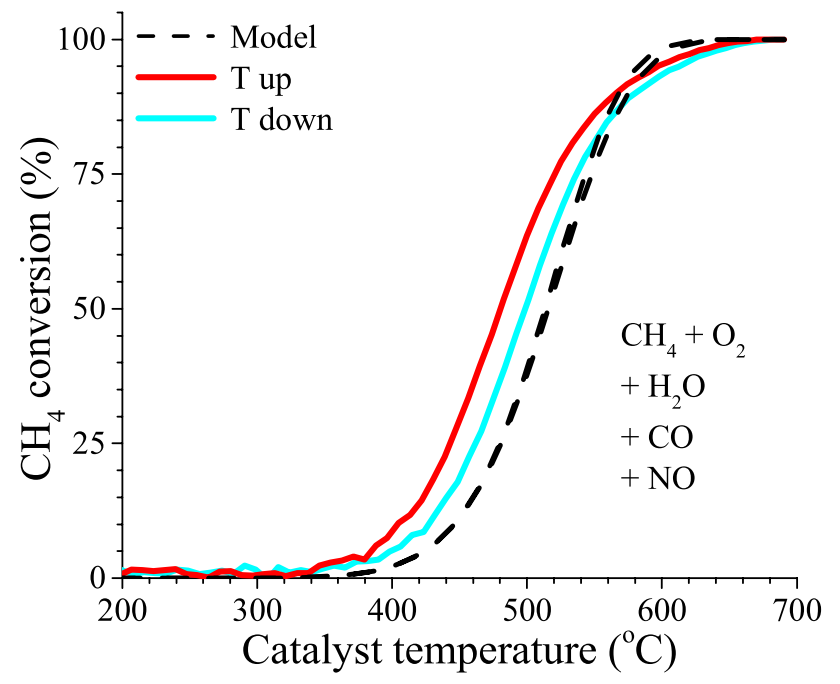

Fig. 6 Data of methane oxidation (solid line) accompanied by data of the kinetic model (dashed line) under heating (red) and cooling (cyan) in a temperature range of $150-700^{\circ} \mathrm{C}$ using the following gas mixture: 500 ppm $\mathrm{CH}_{4}, 500 \mathrm{ppm} \mathrm{NO}, 300 \mathrm{ppm} \mathrm{CO}, 8 \% \mathrm{O}_{2}, 5 \% \mathrm{H}_{2} \mathrm{O}$, Ar

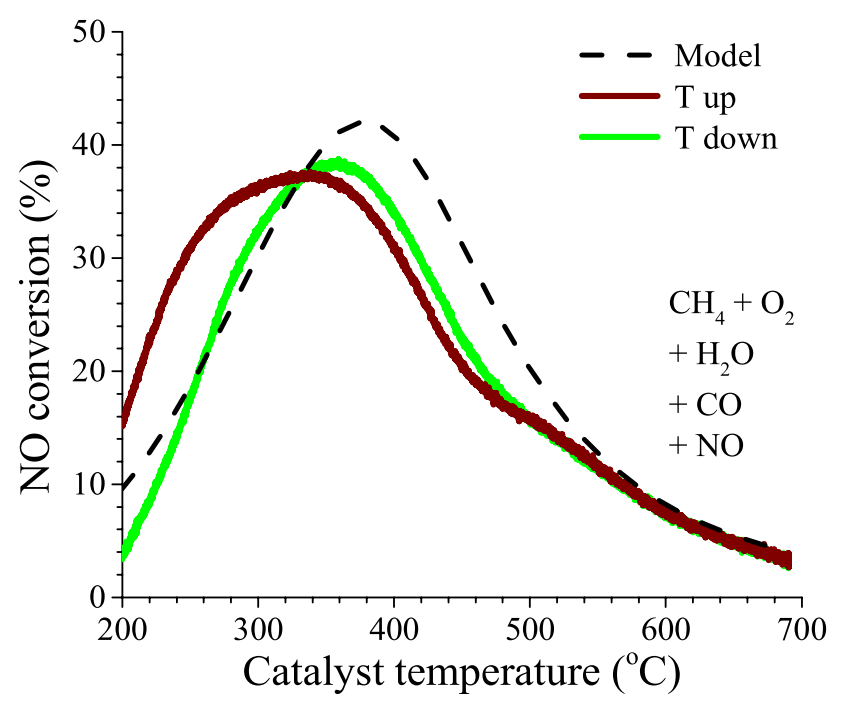

Fig. 7 Data of $\mathrm{NO}$ to $\mathrm{NO}_{2}$ oxidation (solid line) accompanied by data of the kinetic model (dashed line) under heating (brown) and cooling (green) in a temperature range of $150-700^{\circ} \mathrm{C}$ using the following gas mixture: $500 \mathrm{ppm} \mathrm{CH}_{4}, 500 \mathrm{ppm} \mathrm{NO}, 300 \mathrm{ppm} \mathrm{CO}, 8 \%$ $\mathrm{O}_{2}, 5 \% \mathrm{H}_{2} \mathrm{O}, \mathrm{Ar}$

groups that were gradually built up. This mechanism will be further supported by the data shown in Sect. 4.3.

The initial activity loss may be related to the competitive adsorption of $\mathrm{CH}_{4}$ and $\mathrm{H}_{2} \mathrm{O}$ on active sites. In the model, this suggestion is described by the inhibition term included in the rate of reaction R1. Moreover, the significantly lower activity during the cooling step may be attributed to the hydroxyl species formation that was previously suggested for Pd-based catalysts $[6,8,32,55]$. We suggest that this formation has a low rate and quite high energy barrier, resulting in that the water inhibition by the hydroxyl group formation is a slow process and therefore seen more clearly during the cooling step compared to the first heating ramp. Indeed, when adding Reaction R2 to the model describing the hydroxyl species formation and decomposition, the model is able to simulate the experimental features very well, as seen in Fig. 5, and helps to understand that less activity was obtained during the cooling step of the experiment performed under wet conditions.

\subsection{Influence of $\mathrm{NO}$ and $\mathrm{CO}$}

The next set of experiments was performed to test the activity of the Pt-Pd/CeO $-\mathrm{Al}_{2} \mathrm{O}_{3}$ catalyst in methane oxidation using a complex gas mixture including $\mathrm{CO}$ and $\mathrm{NO}$ gases. The resulting methane conversion is shown in Fig. 6. The addition of $\mathrm{CO}$ and $\mathrm{NO}$, under wet conditions, resulted in a $\mathrm{T}_{50}$ of $480^{\circ} \mathrm{C}$ for the heating step compared with $433^{\circ} \mathrm{C}$ for the case without the presence of $\mathrm{CO}$ and NO. For the cooling step, $\mathrm{T}_{50}$ remained almost the same around $498^{\circ} \mathrm{C}$ (compare with $500^{\circ} \mathrm{C}$ for the experiment without $\mathrm{CO}$ and $\mathrm{NO})$. It should be noted that this experiment was conducted directly after the ramping experiment in the presence of $\mathrm{CH}_{4}+\mathrm{O}_{2}+\mathrm{H}_{2} \mathrm{O}$, without any pre-treatment. Thus, significant amount of surface hydroxyls is already present at the start of the experiment shown in Fig. 6, which explains the low activity in this experiment. In the modelling, these two experiments were simulated directly after each other in the same way as the experiment was conducted. During this experiments $\mathrm{CO}$ was fully oxidized to $\mathrm{CO}_{2}$ and since no effect of varying the $\mathrm{CO}$ concentration was observed (see Figs. 8, 9) no terms for $\mathrm{CO}$ were added to the reaction rates. However, a clear NO inhibition effect was observed during transient experiment at constant temperature (see Fig. 8) and this experiment was mainly used to tune the NO inhibition term. In a recent work [32] it was observed a positive effect of $\mathrm{NO}$ addition to the ramping experiment and it was proposed that this effect was relating to interactions between NO and hydroxyl species. This could be the reason for that $\mathrm{T}_{50}$ is lower for the heating ramp for $\mathrm{CO}$ and $\mathrm{NO}$ case compared to the cooling ramp in the foregoing experiment. However, reaction steps for the promoting role of $\mathrm{NO}$ was not added at this stage to the model.

During the experiment with NO present, the NO oxidation was examined and the conversion based on $\mathrm{NO}_{2}$ outlet concentration is reported in Fig. 7. The conversions during the temperature ramp up and down reached almost the same maximum values and were 37 and $38 \%$ for heating and cooling, respectively. NO conversion continued to increase with the temperature until ca. $340^{\circ} \mathrm{C}$, where the $\mathrm{NO}_{2}$ dissociation to form $\mathrm{NO}$ started to become increasingly 


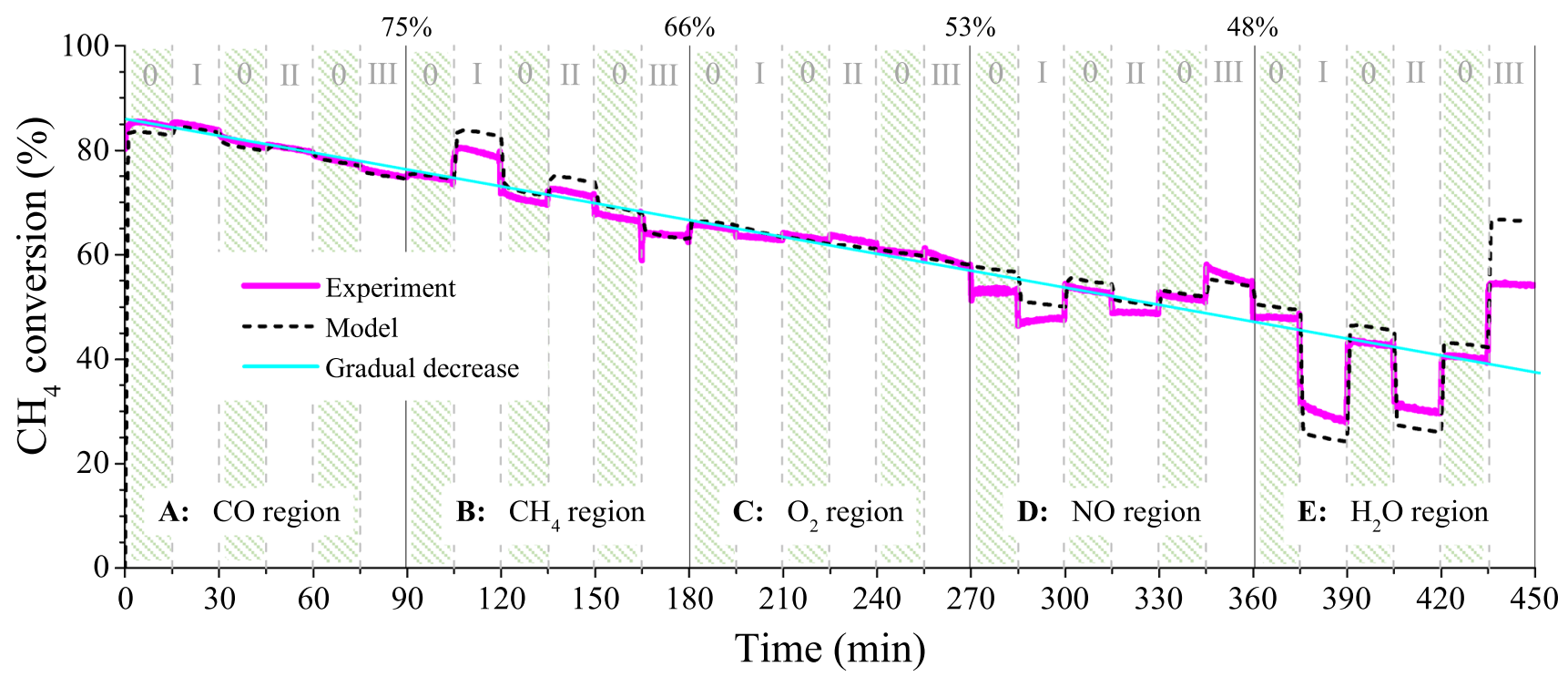

Fig. 8 Gradual deactivation of the $\mathrm{Pt}-\mathrm{Pd} / \mathrm{CeO}_{2}-\mathrm{Al}_{2} \mathrm{O}_{3}$ catalyst under isothermal conditions at $450{ }^{\circ} \mathrm{C}$ with an inlet gas composition (crosshatched area) of $500 \mathrm{ppm} \mathrm{CH}_{4}, 500 \mathrm{ppm} \mathrm{NO}, 300 \mathrm{ppm} \mathrm{CO}, 8 \% \mathrm{O}_{2}, 5 \% \mathrm{H}_{2} \mathrm{O}$ and $\mathrm{Ar}$

Table 4 Concentrations of gas components used in the experiments at constant temperature in connection to Figs. 8 and 9

\begin{tabular}{llclcc}
\hline Step & Region A & Region B & Region C & Region D & Region E \\
& $\mathrm{CO}(\mathrm{ppm})$ & $\mathrm{CH}_{4}(\mathrm{ppm})$ & $\mathrm{O}_{2}(\%)$ & $\mathrm{NO}(\mathrm{ppm})$ & $\mathrm{H}_{2} \mathrm{O}(\%)$ \\
\hline 0-inlet & 300 & 500 & 8 & 500 & 5 \\
I & 700 & 1200 & 14 & 1100 & 11 \\
II & 500 & 800 & 5 & 800 & 9 \\
III & 100 & 200 & 0.14 & 200 & 2 \\
\hline
\end{tabular}

important, due to thermodynamic equilibrium [56]. Step R3 (Tables 2, 3) was added to the kinetic model in order to describe the NO oxidation during methane oxidation and the resulting model is shown in Fig. 7. The model can adequately describe the overall $\mathrm{NO}$ oxidation capacity and the decrease in $\mathrm{NO}_{2}$ formation at higher temperatures due to thermodynamic equilibrium.

\subsection{Hydroxyl Species Accumulation}

Kinetic parameters of the model described in Tables 2 and 3 were also adapted to transient experiments when keeping the temperature constant. In the experiments at $450{ }^{\circ} \mathrm{C}$, the catalyst was exposed to the inlet gas mixture composed of $\mathrm{CH}_{4}, \mathrm{NO}, \mathrm{CO}, \mathrm{O}_{2}$ and $\mathrm{H}_{2} \mathrm{O}$ in Ar. Every 15 min the gas composition was changed according to Fig. 1, as mentioned in the experimental part of the paper.

The results in Fig. 8 demonstrate both methane conversion with time-on-stream and modelling results. During the first 90 min (Region A) when only CO concentration stepwise varied (Table 4), no large fluctuations in methane conversion were detected which means that $\mathrm{CO}$ did not affect the methane oxidation. No $\mathrm{CO}$ was detected at the reactor outlet because of the full conversion to $\mathrm{CO}_{2}$. These results are consistent with the study by Ribeiro et al. [15], in which no effect of $\mathrm{CO}_{2}$ with concentration below $0.5 \%$ on methane oxidation was observed. Moreover, the green crosshatched areas represented regions where the same initial gas concentrations were used. Interestingly, when comparing the steps with the same gas concentrations there was a gradual decrease in methane conversion from 85 to $75 \%$ with time-on-stream during the first $90 \mathrm{~min}$ of the experiment. In addition, the conversion continued to decrease during the whole experiment and as low a conversion as $43 \%$ was recorded during the final section of the experiment. It was proposed that this gradual decrease was due to catalyst deactivation in the presence of water by forming surface hydroxyls. A straight trend line, representing the slope of the deactivation was also inserted into Fig. 8 . It became clear that the deactivation was rather linear over time and that the kinetic model was capable of describing this deactivation well.

During the next 90 min (Region B), the sample was exposed to a gas mixture with different concentration of methane while the concentrations of other gas components were kept constant. The higher methane concentration was introduced into the gas mixture, the higher $\mathrm{CH}_{4}$ conversion was observed. It should be noted that the increased concentration of methane resulted in an increased catalyst temperature (not shown) due to the exothermic effect of the reaction. The increased temperature in the catalyst explains why the conversion was increasing. Furthermore, at the same time less $\mathrm{NO}_{2}$ was formed, which was probably 
related to the temperature increase resulting in an equilibrium shift to $\mathrm{NO}_{2}$ decomposition.

As demonstrated in Fig. 8, Region C, the change in $\mathrm{O}_{2}$ concentration did not affect catalyst activity during $\mathrm{CH}_{4}$ oxidation, which was in agreement with literature data on $\mathrm{CH}_{4}$ oxidation, which was zero order with respect to $\mathrm{O}_{2}$ [15]. In Region D (Fig. 8), the effect of changing the NO concentration was shown. The conversion rapidly decreased when increasing NO concentration and subsequently increased when the NO concentration was lowered. The NO inhibition was well described by the model due to the inhibition term in Reaction R1 (Table 2). In the last part of the experiment, the $\mathrm{H}_{2} \mathrm{O}$ concentration changed. A large activity loss was observed when feeding a higher water amount into the gas flow. However, the activity could be recovered at the same level when the $\mathrm{H}_{2} \mathrm{O}$ concentration switched back from, for example, from 11 to $5 \%$, i.e. to the initial level. This observation supported the suggestion that there were two effects from water, which are accounted for by the model. First, the inhibition due to the water adsorption on active sites resulted in an immediate decrease in methane conversion, which was seen when changing the water concentration in Region D of Fig. 8. Second, the inhibition due to formation of surface hydroxyl groups and their accumulation on the surface resulted in the gradual decrease of activity over time, which was clearly seen by comparing the areas marked with green crosshatches. The model developed in this study described these experimental features well.

The same type of experiment was also conducted at $350{ }^{\circ} \mathrm{C}$ and the results from the experiment and model are depicted in Fig. 9. In Region A, the CO concentration varied and its effect on methane conversion was minor. Thereafter, the methane concentration differed (Region B) and at a lower temperature, an inhibition by methane was observed. Since this inhibition was not observed at higher temperature and in order not to further complicate the model no extra reaction steps were added. In the next region (Region C, Fig. 9) the NO concentration varied and it can be concluded that an inhibition by NO was more significant at high temperature, which can be observed by comparing the results in Figs. 8 and 9. The model well described the effect of changing the NO concentration. In the last region (Region E) the water concentration changed and the model simulated the immediate decrease in methane conversion as the water concentration increased. Moreover, as shown in Fig. 9, there was only a minor deactivation of the catalyst with time-onstream which was noticeable mostly for the $270 \mathrm{~min}$; thereafter, methane conversion reached the steady-state level of 5\%. Thus, it was proposed that the formation of surface hydroxyl species may be an activated process, resulting in that it is significant at $450{ }^{\circ} \mathrm{C}$ but the formation only occurs to a minor extent at $350^{\circ} \mathrm{C}$. The sensitivity analysis of the parameters are shown in Tables 2 and 3. It can be seen that the most sensitive parameters are those relating with the hydroxyl species formation and decomposition as well as the water inhibition term in R1.

The developed kinetic model well described the water inhibition effect observing both during the changing gas concentration, as well as during the slow deactivation occurring at higher temperature due to the formation of surface hydroxyl species.

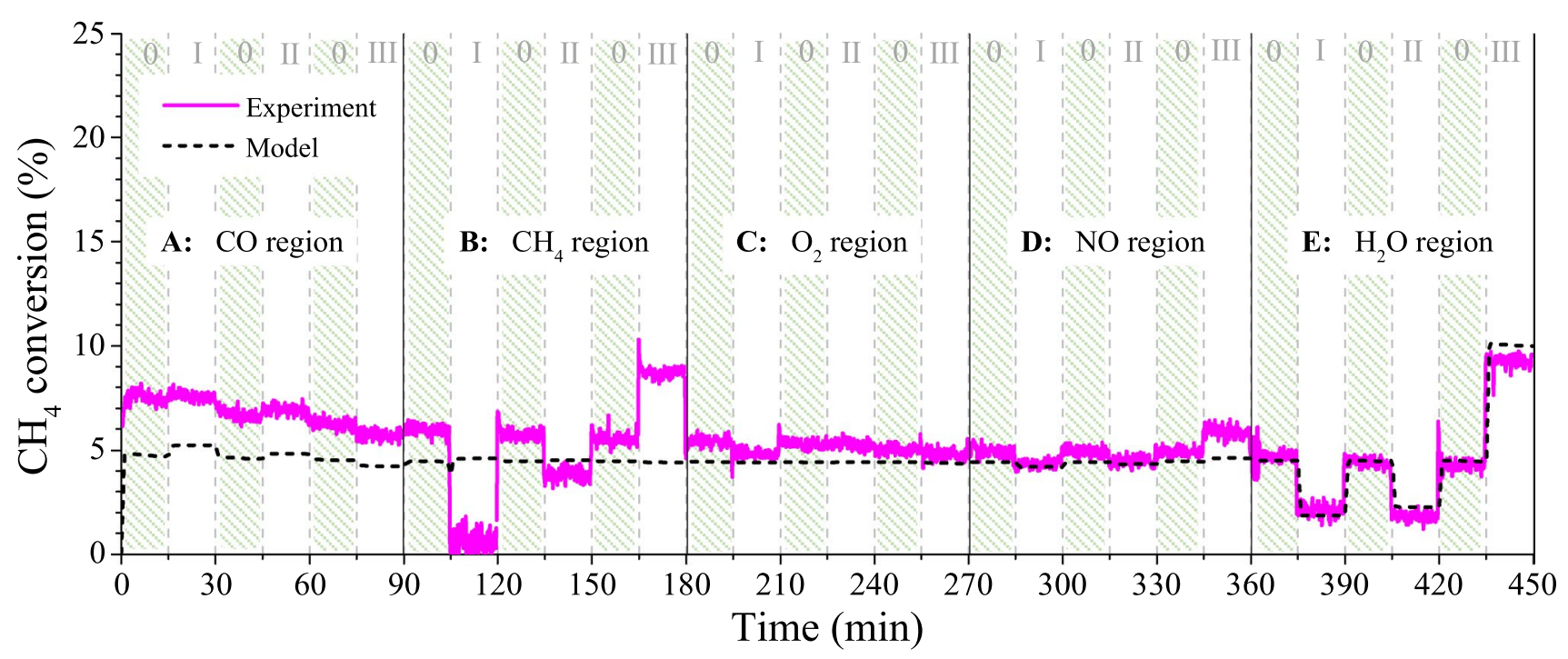

Fig. 9 Gradual deactivation of the $\mathrm{Pt}-\mathrm{Pd} / \mathrm{CeO}_{2}-\mathrm{Al}_{2} \mathrm{O}_{3}$ catalyst under isothermal conditions at $350^{\circ} \mathrm{C}$ with an inlet gas composition (crosshatched area) of $500 \mathrm{ppm} \mathrm{CH}_{4}, 500 \mathrm{ppm} \mathrm{NO}, 300 \mathrm{ppm} \mathrm{CO}, 8 \% \mathrm{O}_{2}, 5 \% \mathrm{H}_{2} \mathrm{O}$ and $\mathrm{Ar}$ 


\section{Conclusions}

Kinetic modelling was used in combination with temperature programmed experiments to investigate methane oxidation under lean conditions using $\mathrm{Pt}-\mathrm{Pd} / \mathrm{CeO}_{2}-\mathrm{Al}_{2} \mathrm{O}_{3}$ as a catalytic system. The catalyst was significantly deactivated by the presence of water, resulting in a $98^{\circ} \mathrm{C}$ increase of the light-off temperature $\left(\mathrm{T}_{50}: 50 \%\right.$ of methane conversion). Moreover, the catalyst demonstrated differential activity during heating and cooling steps, in which the $\mathrm{T}_{50}$ during cooling increased by as much as $181^{\circ} \mathrm{C}$ in the presence of $5 \% \mathrm{H}_{2} \mathrm{O}$ compared with dry conditions. In addition, transient experiments at constant temperature were used for the model development, where concentrations of $\mathrm{CH}_{4}, \mathrm{NO}$, $\mathrm{O}_{2}, \mathrm{CO}$ and $\mathrm{H}_{2} \mathrm{O}$ were varied. Water inhibition is an important deactivation mode during methane oxidation, in which two types of deactivation were observed: (i) immediate decrease in $\mathrm{CH}_{4}$ conversion when increasing the water concentration and (ii) slow deactivation during time-on-stream observed during ramping experiments and during the isothermal experiment where the conversion dropped from 85 to $43 \%$ over the $7.5 \mathrm{~h}$ at $450^{\circ} \mathrm{C}$. Furthermore, only a minor effect on methane conversion was observed when changing the $\mathrm{CO}$ and $\mathrm{O}_{2}$ concentration, whereas increasing the $\mathrm{NO}$ concentration resulted in decreased methane conversion.

The experiments were used as a base to develop a kinetic model for methane oxidation, containing only three reaction steps. First, a global step for $\mathrm{CH}_{4}$ oxidation was introduced, which included inhibition terms for both water and NO. The water inhibition term accounts for the effect of water adsorption on the active sites and is critical in order to describe the rapid changes in methane conversion when changing the water concentration. However, in addition to this immediate effect, it was also observed a slow deactivation with time-on-stream which suggested that inactive hydroxyl species may be formed on the catalyst surface during water exposure, which is the reason for the observed decreased activity. This effect was clearly observed at $450{ }^{\circ} \mathrm{C}$, but only to a minor extent at $350{ }^{\circ} \mathrm{C}$, suggesting that this process is activated. Due to these observations a reaction R2 was added to the model to account for the formation and decomposition of surface hydroxyls. Finally, a reversible reaction $\mathrm{R} 3$ for $\mathrm{NO}$ oxidation was added to the model. The model developed in this study well described the experiments under a variety of conditions.

Acknowledgements The project is a collaboration between AVL MTC Motortestcenter AB, Johnson Matthey AB, Scania CV AB and Chalmers University of Technology. The Swedish Energy Agency (FFI 37179-1 and 37179-2) is gratefully acknowledged for its financial support.

Open Access This article is distributed under the terms of the Creative Commons Attribution 4.0 International License (http:// creativecommons.org/licenses/by/4.0/), which permits unrestricted use, distribution, and reproduction in any medium, provided you give appropriate credit to the original author(s) and the source, provide a link to the Creative Commons license, and indicate if changes were made.

\section{References}

1. Klingstedt F, Neyestanaki AK, Byggningsbacka R, Lindfors LE, Lundén M, Petersson M, Tengström P, Ollonqvist T, Väyrynen J (2001) Appl Catal A 209:301

2. Gélin P, Primet M (2002) Appl Catal B 39:1

3. Lapisardi G, Urfels L, Gélin P, Primet M, Kaddouri A, Garbowski E, Toppi S, Tena E (2006) Catal Today 117:564

4. Kikuchi R, Maeda S, Sasaki K, Wennerström S, Eguchi K (2002) Appl Catal A 232:23

5. Roth D, Gélin P, Primet M, Tena E (2000) Appl Catal A 203:37

6. Persson K, Pfefferle LD, Schwartz W, Ersson A, Järås SG (2007) Appl Catal B Environ 74:242

7. Zhu G, Han J, Zemlyanov DY, Ribeiro FH (2005) J Phys Chem B 109:2331

8. Ciuparu D, Perkins E, Pfefferle LD (2004) Appl Catal A 263:145

9. Burch R, Urbano F, Loader P (1995) Appl Catal A 123:173

10. Gao D, Zhang C, Wang S, Yuan Z, Wang S (2008) Catal Commun 9:2583

11. Park J-H, Kim B, Shin C-H, Seo G, Kim SH, Hong SB (2009) Top Catal 52:27

12. Stasinska B, Machocki A, Antoniak K, Rotko M, Figueiredo JL, Gonçalves F (2008) Catal Today 137:329

13. Okumura K, Shinohara E, Niwa M (2006) Catal Today 117:577

14. Liu Y, Wang S, Gao D, Sun T, Zhang C, Wang S (2013) Fuel Process Technol 111:55

15. Ribeiro FH, Chow M, Dallabetta RA (1994) J Catal 146:537

16. Gélin P, Urfels L, Primet M, Tena E (2003) Catal Today 83:45

17. Burch R (1997) Catal Today 35:27

18. Geus JW, van Giezen JC (1999) Catal Today 47:169

19. Trinchero A, Hellman A, Grönbeck H (2013) Surf Sci 616:206

20. Peskov NV, Slinko MM, Bychkov VY, Korchak VN (2012) Chem Eng Sci 84:684

21. Wolf MM, Zhu H, Green WH, Jackson GS (2003) Appl Catal A 244:323

22. Groppi G, Ibashi W, Valentini M, Forzatti P (2001) Chem Eng Sci 56:831

23. Groppi G, Ibashi W, Tronconi E, Forzatti P (2001) Chem Eng J $82: 57$

24. Fernández J, Marín P, Díez FV, Ordóñez S (2015) Fuel Process Technol 133:202

25. Abbasi R, Wu L, Wanke SE, Hayes RE (2012) Chem Eng Res Des 90:1930

26. Golodets GI (1983) Heterogeneous catalytic reactions involving molecular oxygen, studies in surface science and catalysis, vol 15. Elsevier, Amsterdam

27. Firth JG, Holland HB (1969) Trans Faraday Soc 65:1121

28. Pitchai R, Klier K (1986) Catal Rev 28:13

29. Hurtado P, Ordóñez S, Sastre H, Díez FV (2004) Appl Catal B $51: 229$

30. Specchia S, Conti F, Specchia V (2010) Ind Eng Chem Res 49:11101

31. Alyani M, Smith KJ (2016) Ind Eng Chem Res 55:8309

32. Sadokhina N, Smedler G, Nylén U, Olofsson M, Olsson L (2017) Appl Catal B 200:351

33. Auvray X, Olsson L (2015) Appl Catal B Environ 168-169:342

34. Takeguchi T, Manabe S, Kikuchi R, Eguchi K, Kanazawa T, Matsumoto S, Ueda W (2005) Appl Catal A 293:91 
35. Gremminger AT, Pereira de Carvalho HW, Popescu R, Grunwaldt JD, Deutschmann O (2015) Catal Today 258:470

36. Miller JB, Malatpure M (2015) Appl Catal A 495:54

37. Matam SK, Otal EH, Aguirre MH, Winkler A, Ulrich A, Rentsch D, Weidenkaff A, Ferri D (2012) Catal Today 184:237

38. Lear T, Marshall R, Lopez-Sanchez JA, Jackson SD, Klapötke TM, Bäumer M, Rupprechter G, Freund HJ, Lennon D (2005) J Chem Phys 123:174706

39. Perry R, Green D (1984) Perry's chemical engineers' handbook, 6th edn. McGraw Hill Book Company, New York

40. Metkar PS, Salazar N, Muncrief R, Balakotaiah V, Harold MP (2011) Appl Catal B 104:110

41. Metkar PS, Balakotaiah V, Harold MP (2011) Chem Eng Sci 66:5192

42. Chatterjee D, Burkhardt T, Bandl-Konrad B, Braun T, Tronconi E, Nova I, Ciardelli C (2005) SAE technical paper 2005-01-0965

43. Tronconi E, Cavanna A, Forzatti P (1998) Ind Eng Chem Res 37:2341

44. Beeckman JW (1991) Ind Eng Chem Res 30:428

45. Olsson L, Wijayanti K, Leistner K, Kumar A, Joshi SY, Kamasamudram K, Currier NW, Yezerets A (2015) Appl Catal B 174-175:212
46. Olsson L, Fredriksson M, Blint RJ (2010) Appl Catal B 100:31

47. Colombo M, Nova I, Tronconi E, Koltsakis G (2013) Top Catal 56:177

48. Sjövall H, Blint RJ, Olsson L (2009) Appl Catal B 92:138

49. Van den Bossche M, Grönbeck H (2015) J Am Chem Soc 137:12035

50. NIST Chemistry WebBook (2016) http://webbook.nist.gov/ chemistry/. Accessed 28 Sept 2016)

51. Shwan S, Partridge W, Choi J-S, Olsson L (2014) Appl Catal B 147:1028

52. Ciuparu D, Lyubovsky MR, Altman E, Pfefferle LD, Datye A (2002) Catal Rev 44:593

53. Baldwin TR, Burch R (1990) Catal Lett 6:131

54. Baldwin TR, Burch R (1990) Appl Catal 66:337

55. Schwartz WR, Pfefferle LD (2012) J Phys Chem C 116:8571

56. Olsson L, Westerberg B, Persson H, Fridell E, Skoglundh M, Andersson B (1999) J Phys Chem B 103:10433 